\title{
Protocols of Alcohol Dependents on Rorschach
}

\author{
Dr Thiyam Kiran Singh ${ }^{1}$, Dr. M.V.R. Raju ${ }^{2}$, Noreen Choudhri ${ }^{3}$, \\ Thiyam Sushma Devi ${ }^{4}$, Omprakash Patel ${ }^{5}$, Dr. Subhash Das ${ }^{6}$
}

\section{ABSTRACT}

This study is to bring some of the patterns of Alcohol Dependents on Rorschach test. In this study random sampling technique was used through which a sample of 20 Alcohol Dependents and 20 Non dependents were included with the mean age of 33.60 years and 30.70 years. All participants were administered Rorschach Ink Blot test to see the different patterns between the groups. The result of the study reflects that there exists a significant difference between groups in the area of total responses, contents categories, space responses (S), ordinary (O) responses, synthesized responses $(\mathrm{V} /+)$, vague responses $(\mathrm{V})$, form $(\mathrm{F})$ responses, Popular $(\mathrm{P})$ responses, Raw sum6 and Wgtd sum6. It was found that Non dependents produce more in: total responses, contents categories, space responses, ordinary responses, form responses and popular responses. Whereas alcohol dependents reflect more response in the areas of: vague responses, synthesized responses, unusual responses, Rawsum6 and Wgtdsum6.

Keywords: Alcohol dependents, Non-Alcohol Dependents, Rorschach, Protocol.

Rorschach is an Inkblot Personality Assessment Tests which Clinical Psychologist used as one of the most important test in their clinical practice. Even in India the Rorschach test is widely used and enjoys the highest rank among the tests used for psycho diagnosis and assessment of personality (Dubey, 1982). The clinical use of a psychological test like the Rorschach requires the existence of norms for normal individuals and also patients with various psychiatric disorders. Comparatively there are a few studies on children and adolescent using the Rorschach test in India. Moreover, within the researches conducted in India, the norms for normal subjects and patients with various psychiatric disorders established by various workers differ

\footnotetext{
${ }^{1}$ Associate Professor (Clinical Psychology), Government Medical College \& Hospital, Chandigarh, India

${ }^{2}$ Professor and Head, Department of Psychology, Andhra University, India

${ }^{3}$ Clinical Psychologist, Psychiatric Centre Jaipur, India

${ }^{4}$ Uripok Haobam Dewan Leikei, Imphal, Manipur, India

${ }^{5}$ Research Scholar, Barsi, Haryana, India

${ }^{6}$ Assistant Professor, Government Medical College \& Hospital, Chandigarh, India

*Responding Author

(C) 2016 K Singh, M Raju, N Choudhri, T Devi, O Patel, S Das; licensee IJIP. This is an Open Access Research distributed under the terms of the Creative Commons Attribution License (http://creativecommons.org/licenses/by/2.0), which permits unrestricted use, distribution, and reproduction in any Medium, provided the original work is properly cited.
} 


\section{Protocols of Alcohol Dependents on Rorschach}

considerably (Bagh, 1955; Roy Chaudhuri \& Maitra, 1965; Sethi et al, 1976; Dubey, 1982, Singh \& Verma, 1990). Clinical Psychology in India has a relatively short history. As an applied field of psychology, it is not very old. For a short while, the training of clinical psychology was started in 1951 at Banaras Hindu University, but it really got started with DM and SP now M. Phil in Clinical Psychology at Bangalore in 1956 (Verma, 1996). Central Institute of Psychiatry started training for clinical psychologists in 1962 (Nizamie and Goyal, 2010). At present 16 (IACP record) to 20 institutions and universities started running this course. These institutions provide training in Rorschach as per India is concerned.Prior to the 1970s, there were five primary scoring systems for how people responded to the inkblots. They were dominated by two - the Beck and the Klopfer systems. Three other that were used less often were the Hertz, Piotrowski and the Rapaport-Schafer systems. In 1969, John E. Exner, Jr. published the first comparison of these five systems entitled The Rorschach Systems (Femingham, 2015). In almost all of the systems do not try to find out the pattern of alcohol dependents on Rorschach. In this study an attempt is made to get some ideas regarding what kind of patterns might occur in alcohol dependents group by analysing the responses (protocols) of them in Rorschach test so that the findings could help in the field of clinical practice of psychology.

\section{METHODOLOGY}

\section{Objectives:}

1. To study the Protocols of Alcohol Dependents on Rorschach Test.

2. To compare the protocols of Alcohol Dependents with the protocols of Non Dependents.

\section{Sample Details:}

The sample consists of 20 Alcohol Dependents and 20 Non Dependents of the mean age groups of 33.60 and 30.70 respectively.

\section{Alcohol Dependents}

Inclusion Criteria:

1. Male who fulfill the criteria of Alcohol dependents according to ICD-10.

2. Those who can give their consent for study.

\section{Exclusion Criteria:}

1. Social Drinker.

2. Co morbid Psychiatric illness at diagnostic Level according to ICD-10.

\section{Non Alcohol Dependents}

Inclusion Criteria:

1. Male who do not fulfill the criteria of Alcohol Dependents according to ICD-10.

2. Those who can give their consent for study.

Exclusion Criteria:

1. Co morbid Psychiatric illness at diagnostic Level according to ICD-10. 


\section{Protocols of Alcohol Dependents on Rorschach}

\section{Tools Used:}

\section{Rorschach test (Exner, 2005):}

The Rorschach Inkblot Test is a projective psychological test consisting of 10 inkblots printed on cards (five in black and white, five in color) created in 1921 with the publication of Psychodiagnostik by Hermann Rorschach. During the 1940s and 1950s, the test was synonymous with clinical psychology. Throughout much of the 20th century, the Rorschach inkblot test was a commonly used and interpreted psychological test. In surveys in 1947 (Louttit and Browne) and 1961 (Sundberg), for instance, it was the fourth and first, respectively, most frequently used psychological test. Prior to the 1970s, there were five primary scoring systems for how people responded to the inkblots. They were dominated by two - the Beck and the Klopfer systems. Three other that were used less often were the Hertz, Piotrowski and the Rapaport-Schafer systems. In 1969, Exner, Jr. published the first comparison of these five systems entitled The Rorschach Systems. Dr. Exner developed the Comprehensive System as a scientifically valid, clinically useful, and reliable method of using the Rorschach Inkblot Test. He did this by working with a number of Rorschach experts (Klopfer, Beck, Hertz, etc.) and realized that no one system could be defended. While there was some research supportive of different aspects of each of the systems, none of them had a broad based research foundation. To help the Rorschach gain acceptance and utility, he developed a research plan to test various aspects of the test. In addition, he developed reliable and valid rules of administration.

\section{Procedure}

A sample of 20 Alcohol Dependents and 20 Non Dependents were selected from Government Medical College and Hospital, Chandigarh who fulfilled inclusion criteria. They were given consent forms and also explain the purpose of study properly. It was emphasized that participants in the study should be voluntary and they could withdraw any time if they are not willing to continue. Participants who fulfilled inclusion criteria were administered Rorschach to assess their pattern of responses on Rorschach test.

\section{Statistical Analysis}

Statistical analysis was done with the help of Statistical Package of Social Science (SPSS-20.0). Mean and Standard Deviation were calculated followed by t- test to compare between two groups namely- Alcohol Dependents and Non Dependents.

\section{RESULTS}

Table-1 shows, the mean and SD of Alcohol dependents and Non Dependents. The result found that the mean age of alcohol dependents was $33.60( \pm 8.431)$ and the mean of Non Dependents was $30.70( \pm 7.34)$ which showed the mean age of both the groups did not have much variation. Table-2 shows, comparison of Alcohol Dependents and non dependents with regards to response. The result found t-value was 2.587 which was statistically significant $(\mathrm{P}<0.01)$ which means the total number of responses were significantly higher at non dependents groups than Alcohol 


\section{Protocols of Alcohol Dependents on Rorschach}

dependents groups.Table-3 shows, comparison of Alcohol Dependents and non dependents with regards to contents. The result found t-value of 1.993 which was statistically significant $(\mathrm{P}<$ 0.05 ) which proclaim that Non dependents group were significantly higher in content categories than alcohol dependents group.Table-4 shows, comparison of Alcohol Dependents and non dependents with respect to location and Developmental Quality (DQ). The result found t-values of 2.260 in the domain of Space $(S)$ which was statistically significant $(\mathrm{P}<0.01)$. This reflects non dependents were significantly higher in $\mathrm{S}$ response than alcohol dependents. In respect to DQ, $\mathrm{t}-$ values were; 3.028, 2.185 and 1.972 under the domains of Ordinary (O), Synthesized (V/+) and Vague (V) which were statistically significant. These provides the impression that Non dependents were significantly produce higher ' $O$ ' responses where as Alcohol dependents group produce significantly more responses at the domain of V/+ and V. Table-5 shows, comparison of Alcohol Dependents and non dependents with regards to Form Quality (FQ). The result found tvalue of 5.039 and 2.129 in the domain of ordinary (O) and Unusual (U) which was statistically significantly $(\mathrm{P}<0.01$ and $\mathrm{P}<0.05)$. This provides the cognition that Non dependents group significantly produce more ' $O$ ' responses and Alcohol dependents group provide more ' $U$ ' responses. Likewise, the result repeats when we have an eye at the area of $\mathrm{W}+\mathrm{D}$. Table -6 shows, comparison of Alcohol Dependents and Non dependents with respect to form (F). The result found t- value of 4.358 which was statistically significant $(\mathrm{P}<0.01)$. This finding interprets that Non-dependents group produce significance higher F responses than Alcohol dependence group. Table -7 shows, comparison of Alcohol Dependents and non dependents with respect to Popular response (P), Lambda (L), Affect ratio (Afr), Raw Sum6 and Wgtd Sum6. The result found Non dependents group were significantly responded more $\mathrm{P}(\mathrm{t}=6.883, \mathrm{P}<0.01)$, where as Alcohol dependents responded more Rawsum6 $(\mathrm{t}=$ 4.502, $\mathrm{P}<0.01)$ and wgtdsum6 $(\mathrm{t}=6.538, \mathrm{P}<0.01)$.

\section{DISCUSSIONS}

The present study attempts to get some ideas regarding patterns of Alcohol dependents group by analyzing the responses (protocols) of them in Rorschach test so that the findings could help in the field of clinical practice of psychology. The result found, the total number of responses, content categories, space response and ordinary response were significantly higher at non dependents groups than Alcohol dependents groups. This may be because alcohol dependents are poor in creative thinking. They can't sift their ideas from one to another quickly. They have cognitive impairment and frontal lobe dysfunction. This is supported by the study of Bernardin et al (2014) who found that Chronic excessive alcohol consumption induces cognitive impairments mainly affecting executive functions, episodic memory and visuospatial capacities related to multiple brain lesions. These cognitive impairments not only determine everyday management of these patients, but also impact on the efficacy of management and may compromise the abstinence prognosis. Moselhy, Georgiou, and Kahn (2001) did Neurophysiological studies with positron emission tomography and single photon emission computed tomography in alcohol dependents. The result found decrease frontal lobe glucose utilization and reduced cerebral blood flow. There is also evidence from neuropsychological studies that there are specific deficits in 


\section{Protocols of Alcohol Dependents on Rorschach}

alcohol dependents that suggest frontal lobe dysfunction which plays the role of thinking and decision making.

The results found Non dependents group are significantly responded more $\mathrm{F}$ and Popular (P) responses where as alcohol dependents responded more V/+, V, U, Raw sum6 and wgtdsum6 responses. This may be because alcohol dependents are unable to think logically, optimally and also unable to produce more clear executive functional concepts. They also have poor visuospatial cognition. Supportively, Brevers et al. (2014) found that alcohol dependent individuals are impaired in their ability to decide optimally in multiple facets of uncertainty and that at least some aspects of these deficits are linked to poor working memory processes. In another study of Berman et al (2014) found that alcohol dependents have decrease memory, executive functions, emotion and psychosocial skills, visuospatial cognition and psychomotor abilities are particularly affected. In accordance with this pattern of deficits, the brain networks that underlie the most impaired functions involve the frontocerebellar system and mesocortico limbic circuitry.

\section{CONCLUSION}

1. Alcohol dependents produce significantly less response compares to non dependents groups.

2. Alcohol Dependents responded significantly less content categories than Non Alcohol dependents.

3. Alcohol Dependents responds Significantly less ' $S$ ' responses and ' $O$ ' responses.

4. Alcohol dependents group produce significantly more responses at the domain of $\mathrm{V} /+$ and V.

5. Alcohol dependents group significantly produce more ' $U$ ' responses.

6. Alcohol dependents produce significantly less $\mathrm{F}(\mathrm{o}, \mathrm{u})$ responses.

7. Alcohol Dependents produce significantly less popular response (P).

8. Alcohol dependents significantly responded more Rawsum6 and wgtdsum6.

\section{LIMITATIONS AND FUTURE DIRECTIONS}

1. Sample size required to increase.

2. The mean age of both groups must be similar.

3. The differences in the pattern of response in comparison with other Psychiatric illness required to rule out.

\section{Acknowledgments}

The authors appreciate all those who participated in the study and helped to facilitate the research process.

\section{Conflict of Interests}

The author declared no conflict of interests. 


\section{REFERENCES}

Bagh, D. (1955). Use of Rorschach's ink blot test among school adolescents. Indian Journal of Psychology. 30: 61-64.

Berman, M.O., Valmas, M.M., Sawyer, K.S., Ruiz, S.M., Luhar, R.B., \& Gravitz, Z.R. (2014). Profiles of Impaired, Spared, and Recovered Neuropsychological Processes in Alcoholism. Retrieved from http://www.ncbi.nlm.nih.gov/pmc/articles/PMC4515358/ on 15/11/2015.

Bernardin, F., Bosser, A.M., \& François Paille, F. (2014). Cognitive Impairments in AlcoholDependent Subjects. Front Psychiatry, 5(1), 78. Retrieved from http://www.ncbi.nlm.nih.gov/pmc/articles/PMC4099962/ on 15/11/2015.

Brevers, D., Bechara, A., Cleeremans, A., Kornreich, C., Verbanck, P., \& Noel, X. (2014).Impaired decision-making under risk in individuals with alcohol dependence. Alcohol Clin Exp Res., 38(7), 1924-1931. Retrieved from http://www.ncbi.nlm.nih.gov/pmc/articles/PMC4115290/ on 15/11/2015.

Dubey, B.L. (1982). A pragmatic view of the Rorschach Inkblot Technique. Agra: National Psychological Corporation.

Exner, J. (2005). A Rorschach Workbook for the Comprehensive System (5th ed.) Asheville, NC: Rorschach Workshops. Retrieved from http://www.rorschachtraining.com/rorschach-comprehensive-system-current-issues/ on 3/10/2015.

Femingham, J (2015). Rorschach Inkblot Test. Retrieved from http://psychcentral.com/lib/rorschach-inkblot-test/ on 19/11/2015.

Moselhy, H.F., Georgiou, G., \& Kahn. A. (2001). Frontal lobe changes in Alcoholosm: A review of the Literature. Alcohol \& Alcoholism, 36(5), 357-368. Retrieved from http://alcalc.oxfordjournals.org/content/36/5/357 on 15/11/2015.

Nizamie, S.H., \& Goyal, N. (2010). History of psychiatry in India. Indian J Psychiatry. 52(1), $7-$ 12.

Raychaudhuri, M., \& Maitra, A.K. (1965). A Rorschach study of normal, convicted and incipient delinquent adolescents. Rorschiana Japonica. 8: 170-184.

Sethi, B.S., Gupta, S.C., Agarwal, S.S. \& Sinha, P.K. (1976). A psychosocial study delinquents with special reference to aggression. Indian Journal of Psychiatry. 118 : 157-163.

Singh, O.P., \& Verma, R. (1990). Rorschach responses of delinquent and non delinquent adolescents : A discriminant analysis. Indian Journal of Criminology. 18 : 47-60.

Verma, S.K. (1996). Clinical Psychology in India. Journal of the Indian Academy of Applied Psychology, 22 (1-2), 1-10. 
Table-1: Shows the mean age and SD of alcohol dependents.

\begin{tabular}{|l|l|c|c|c|}
\hline \multirow{3}{*}{ Age } & Groups & N & Mean & Std. Deviation \\
\cline { 2 - 5 } & $\begin{array}{l}\text { Alcohol } \\
\text { Dependents }\end{array}$ & 20 & 33.6000 & 8.43177 \\
\cline { 2 - 5 } & Non Dependents & 20 & 30.7000 & 7.34202 \\
\hline
\end{tabular}

Table-2: Comparison of Alcohol Dependents and non dependents with regards to response.

\begin{tabular}{|l|l|c|c|c|c|}
\hline & Groups & N & Mean & $\begin{array}{c}\text { Std. } \\
\text { Deviation }\end{array}$ & t- Value \\
\hline \multirow{2}{*}{ T. Response } & $\begin{array}{l}\text { Alcohol } \\
\text { Dependents }\end{array}$ & 20 & 21.9000 & 6.54458 & \multirow{2}{*}{$2.587^{* *}$} \\
\cline { 2 - 5 } & $\begin{array}{l}\text { Non } \\
\text { Dependents }\end{array}$ & 20 & 28.8000 & 9.97154 & \\
\hline
\end{tabular}

** Significant at 0.01 level, *Significant at 0.05 level

Table-3: Comparison of Alcohol Dependents and non dependents with regards to contents.

\begin{tabular}{|l|l|l|l|l|l|}
\hline & Groups & N & Mean & SD & t-Value \\
\hline \multirow{3}{*}{ Contents } & $\begin{array}{l}\text { Alcohol } \\
\text { Dependents }\end{array}$ & 20 & 6.7500 & 2.35919 & \multirow{2}{*}{$1.993^{*}$} \\
\cline { 2 - 5 } & $\begin{array}{l}\text { Non } \\
\text { Dependents }\end{array}$ & 20 & 8.3000 & 2.55672 & \\
\hline
\end{tabular}

** Significant at 0.01 level, *Significant at 0.05 level

Table-4: Comparison of Alcohol Dependents and non dependents with respect to location and Developmental Quality (DQ)

\begin{tabular}{|l|l|l|c|c|c|c|}
\hline & & Groups & N & Mean & $\begin{array}{c}\text { Std. } \\
\text { Deviation }\end{array}$ & t- Value \\
\hline \multirow{2}{*}{ Locations } & \multirow{2}{*}{ W } & $\begin{array}{l}\text { Alcohol } \\
\text { Dependents }\end{array}$ & 20 & 5.2000 & 3.25415 & 1.608 \\
\cline { 2 - 6 } & \multirow{2}{*}{$\begin{array}{l}\text { Non } \\
\text { Dependents }\end{array}$} & 20 & 6.7500 & 2.82610 & \\
\cline { 2 - 6 } & $\begin{array}{l}\text { Alcohol } \\
\text { Dependents }\end{array}$ & 20 & 13.9500 & 5.80812 & 1.604 \\
\cline { 2 - 5 } & $\begin{array}{l}\text { Non } \\
\text { Alcohol } \\
\text { Dependents }\end{array}$ & 20 & 17.5500 & 8.18519 & \\
\cline { 2 - 5 } & Dd & $\begin{array}{l}\text { Alcohol } \\
\text { Dependents }\end{array}$ & 20 & 1.8000 & 1.73509 & 1.407 \\
\cline { 2 - 5 } & $\begin{array}{l}\text { Non } \\
\text { Alcohol } \\
\text { Dependents }\end{array}$ & 20 & 2.7000 & 2.27342 & \\
\hline
\end{tabular}

(c) The International Journal of Indian Psychology, ISSN 2348-5396 (e)| ISSN: 2349-3429 (p) | 86 
Protocols of Alcohol Dependents on Rorschach

\begin{tabular}{|c|c|c|c|c|c|c|}
\hline & & Groups & $\mathbf{N}$ & Mean & $\begin{array}{c}\text { Std. } \\
\text { Deviation }\end{array}$ & t- Value \\
\hline & \multirow[t]{2}{*}{$\mathrm{S}$} & $\begin{array}{l}\text { Alcohol } \\
\text { Dependents }\end{array}$ & 20 & 1.3000 & 1.34164 & \multirow[t]{2}{*}{$2.260 *$} \\
\hline & & $\begin{array}{l}\text { Non } \\
\text { Dependents }\end{array}$ & 20 & 2.3000 & 1.45458 & \\
\hline \multirow{8}{*}{ DQ } & \multirow[t]{2}{*}{+} & $\begin{array}{l}\text { Alcohol } \\
\text { Dependents }\end{array}$ & 20 & 3.2500 & 2.31414 & \multirow[t]{2}{*}{0.959} \\
\hline & & $\begin{array}{l}\text { Non } \\
\text { Dependents }\end{array}$ & 20 & 4.5500 & 5.60521 & \\
\hline & \multirow[t]{2}{*}{$\mathrm{O}$} & $\begin{array}{l}\text { Alcohol } \\
\text { Dependents }\end{array}$ & 20 & 15.7000 & 5.89469 & \multirow[t]{2}{*}{$3.028 * *$} \\
\hline & & $\begin{array}{l}\text { Non } \\
\text { Dependents }\end{array}$ & 20 & 22.8500 & 8.76161 & \\
\hline & \multirow[t]{2}{*}{$\mathrm{V} /+$} & $\begin{array}{l}\text { Alcohol } \\
\text { Dependents }\end{array}$ & 20 & .4000 & .68056 & \multirow[t]{2}{*}{$2.185 *$} \\
\hline & & $\begin{array}{l}\text { Non } \\
\text { Alcohol } \\
\text { Dependents }\end{array}$ & 20 & .0500 & .22361 & \\
\hline & \multirow[t]{2}{*}{$\mathrm{V}$} & $\begin{array}{l}\text { Alcohol } \\
\text { Dependents }\end{array}$ & 20 & 2.5500 & 2.70429 & \multirow[t]{2}{*}{$1.972 *$} \\
\hline & & $\begin{array}{l}\text { Non } \\
\text { Dependents }\end{array}$ & 20 & 1.1500 & 1.66307 & \\
\hline
\end{tabular}

** Significant at 0.01 level, *Significant at 0.05 level

Table-5: Comparison of Alcohol Dependents and non dependents with regards to Form Quality (FQ).

\begin{tabular}{|c|c|c|c|c|c|c|}
\hline$\overline{F Q}$ & & Groups & $\mathbf{N}$ & Mean & Std. Deviation & t-Value \\
\hline \multirow{5}{*}{ FQX } & + & $\begin{array}{l}\text { Alcohol Dependents } \\
\text { Non Alcohol } \\
\text { Dependents }\end{array}$ & $\begin{array}{l}20 \\
20\end{array}$ & $\begin{array}{l}.0000 \\
.0000\end{array}$ & $\begin{array}{l}.00000 \\
.00000\end{array}$ & 0.000 \\
\hline & $\mathrm{O}$ & $\begin{array}{l}\text { Alcohol Dependents } \\
\text { Non Alcohol } \\
\text { Dependents }\end{array}$ & $\begin{array}{l}20 \\
20\end{array}$ & $\begin{array}{r}7.2000 \\
16.5500\end{array}$ & $\begin{array}{l}5.09489 \\
6.54921\end{array}$ & $5.039 * *$ \\
\hline & $\overline{\mathrm{U}}$ & $\begin{array}{l}\text { Alcohol Dependents } \\
\text { Non Alcohol } \\
\text { Dependents }\end{array}$ & $\begin{array}{l}20 \\
20\end{array}$ & $\begin{array}{l}4.9500 \\
2.9000\end{array}$ & $\begin{array}{l}3.95335 \\
1.71372\end{array}$ & $2.129 *$ \\
\hline & - & $\begin{array}{l}\text { Alcohol Dependents } \\
\text { Non Alcohol } \\
\text { Dependents }\end{array}$ & $\begin{array}{l}20 \\
20\end{array}$ & $\begin{array}{l}7.4500 \\
8.4000\end{array}$ & $\begin{array}{l}3.33206 \\
4.30911\end{array}$ & 0.780 \\
\hline & None & $\begin{array}{l}\text { Alcohol Dependents } \\
\text { Non Alcohol } \\
\text { Dependents }\end{array}$ & $\begin{array}{l}20 \\
20\end{array}$ & $\begin{array}{l}.5500 \\
.7000\end{array}$ & $\begin{array}{l}1.70062 \\
1.17429\end{array}$ & 0.325 \\
\hline
\end{tabular}

(c) The International Journal of Indian Psychology, ISSN 2348-5396 (e)| ISSN: 2349-3429 (p) | 87 
Protocols of Alcohol Dependents on Rorschach

\begin{tabular}{|c|c|c|c|c|c|c|}
\hline $\mathbf{F Q}$ & & Groups & $\mathbf{N}$ & Mean & Std. Deviation & t-Value \\
\hline \multirow{5}{*}{ MQual } & + & $\begin{array}{l}\text { Alcohol Dependents } \\
\text { Non Alcohol } \\
\text { Dependents }\end{array}$ & $\begin{array}{l}20 \\
20\end{array}$ & $\begin{array}{l}.0000 \\
.0500\end{array}$ & $\begin{array}{l}.00000 \\
.22361\end{array}$ & 1.000 \\
\hline & $\mathrm{O}$ & $\begin{array}{l}\text { Alcohol Dependents } \\
\text { Non Alcohol } \\
\text { Dependents }\end{array}$ & $\begin{array}{l}20 \\
20\end{array}$ & $\begin{array}{r}.4500 \\
1.0000\end{array}$ & \begin{tabular}{r|}
.60481 \\
1.29777
\end{tabular} & 1.718 \\
\hline & $\bar{U}$ & $\begin{array}{l}\text { Alcohol Dependents } \\
\text { Non Alcohol } \\
\text { Dependents }\end{array}$ & $\begin{array}{l}20 \\
20\end{array}$ & $\begin{array}{l}.3500 \\
.0500\end{array}$ & $\begin{array}{l}.81273 \\
.22361\end{array}$ & 1.592 \\
\hline & - & $\begin{array}{l}\text { Alcohol Dependents } \\
\text { Non Alcohol } \\
\text { Dependents }\end{array}$ & $\begin{array}{l}20 \\
20\end{array}$ & $\begin{array}{l}.7500 \\
.0000\end{array}$ & $\begin{array}{r}2.26820 \\
.00000\end{array}$ & 1.479 \\
\hline & None & $\begin{array}{l}\text { Alcohol Dependents } \\
\text { Non Alcohol } \\
\text { Dependents }\end{array}$ & $\begin{array}{l}20 \\
20\end{array}$ & $\begin{array}{l}.2000 \\
.0000\end{array}$ & $\begin{array}{l}.61559 \\
.00000\end{array}$ & 1.453 \\
\hline \multirow{5}{*}{$\mathrm{W}+\mathrm{D}$} & + & $\begin{array}{l}\text { Alcohol Dependents } \\
\text { Non Alcohol } \\
\text { Dependents }\end{array}$ & $\begin{array}{l}20 \\
20\end{array}$ & $\begin{array}{l}.0000 \\
.0500\end{array}$ & $\begin{array}{l}.00000 \\
.22361\end{array}$ & 1.000 \\
\hline & $\mathrm{O}$ & $\begin{array}{l}\text { Alcohol Dependents } \\
\text { Non Alcohol } \\
\text { Dependents }\end{array}$ & $\begin{array}{l}20 \\
20\end{array}$ & $\begin{array}{r}7.2000 \\
14.6000\end{array}$ & $\begin{array}{l}6.11814 \\
5.45218\end{array}$ & $4.038^{* *}$ \\
\hline & $\bar{U}$ & $\begin{array}{l}\text { Alcohol Dependents } \\
\text { Non Alcohol } \\
\text { Dependents }\end{array}$ & 20 & $\begin{array}{l}4.9000 \\
2.3000\end{array}$ & $\begin{array}{l}3.59678 \\
1.71985\end{array}$ & $2.916^{* *}$ \\
\hline & - & $\begin{array}{l}\text { Alcohol Dependents } \\
\text { Non Alcohol } \\
\text { Dependents }\end{array}$ & $\begin{array}{l}20 \\
20\end{array}$ & $\begin{array}{l}6.1500 \\
6.4000\end{array}$ & $\begin{array}{l}2.71981 \\
3.54520\end{array}$ & 0.250 \\
\hline & None & $\begin{array}{l}\text { Alcohol Dependents } \\
\text { Non Alcohol } \\
\text { Dependents }\end{array}$ & 20 & $\begin{array}{l}.5500 \\
.2000\end{array}$ & $\begin{array}{r}1.70062 \\
.52315\end{array}$ & 0.880 \\
\hline
\end{tabular}

** Significant at 0.01 level, *Significant at 0.05 level

Table 6: Comparison of Alcohol dependents and Non dependents with respect to form (F).

\begin{tabular}{|c|c|c|c|c|c|}
\hline Determinants & Groups & $\mathbf{N}$ & Mean & $\begin{array}{c}\text { Std. } \\
\text { Deviation }\end{array}$ & t-Value \\
\hline \multirow[t]{2}{*}{$\mathrm{F}(\mathrm{o}, \mathrm{u})$} & $\begin{array}{l}\text { Alcohol } \\
\text { Dependents }\end{array}$ & 20 & 10.2500 & 8.05818 & \multirow{2}{*}{$4.358^{* *}$} \\
\hline & $\begin{array}{l}\text { Non } \\
\text { Dependents }\end{array}$ & 20 & 23.3000 & 10.69727 & \\
\hline
\end{tabular}

** Significant at 0.01 level, *Significant at 0.05 level

(C) The International Journal of Indian Psychology, ISSN 2348-5396 (e)| ISSN: 2349-3429 (p) | 88 
Table -7: Comparison of Alcohol Dependents and non dependents with respect to Popular response (P), Lambda (L), Affect ratio (Afr), Raw Sum6 and Wgtd Sum6.

\begin{tabular}{|c|c|c|c|c|c|}
\hline & Groups & $\mathbf{N}$ & Mean & $\begin{array}{c}\text { Std. } \\
\text { Deviation }\end{array}$ & t-Value \\
\hline \multirow[t]{2}{*}{$\mathrm{P}$} & $\begin{array}{l}\text { Alcohol } \\
\text { Dependents }\end{array}$ & 20 & 2.0500 & 1.46808 & \multirow{2}{*}{$6.883^{* *}$} \\
\hline & $\begin{array}{l}\text { Non } \\
\text { Dependents }\end{array}$ & 20 & 6.2000 & 2.26181 & \\
\hline \multirow[t]{2}{*}{$\mathrm{L}$} & $\begin{array}{l}\text { Alcohol } \\
\text { Dependents }\end{array}$ & 20 & 5.7965 & 5.30400 & \multirow{2}{*}{0.481} \\
\hline & $\begin{array}{l}\text { Non } \\
\text { Dependents }\end{array}$ & 20 & 6.5705 & 4.85276 & \\
\hline \multirow[t]{2}{*}{ Afr } & $\begin{array}{l}\text { Alcohol } \\
\text { Dependents }\end{array}$ & 20 & .5480 & .18341 & \multirow{2}{*}{0.139} \\
\hline & $\begin{array}{l}\text { Non } \\
\text { Dependents }\end{array}$ & 20 & .5405 & .15719 & \\
\hline \multirow[b]{2}{*}{ Rawsum6 } & $\begin{array}{l}\text { Alcohol } \\
\text { Dependents }\end{array}$ & 20 & 2.4000 & 1.27321 & \multirow[t]{2}{*}{$4.502^{* *}$} \\
\hline & $\begin{array}{l}\text { Non } \\
\text { Dependents }\end{array}$ & 20 & .8000 & .95145 & \\
\hline \multirow[t]{2}{*}{ Wgtdsum6 } & $\begin{array}{l}\text { Alcohol } \\
\text { Dependents } \\
\end{array}$ & 20 & 22.2500 & 12.85087 & \multirow[t]{2}{*}{$6.538 * *$} \\
\hline & $\begin{array}{l}\text { Non } \\
\text { Dependents }\end{array}$ & 20 & 2.8000 & 3.44277 & \\
\hline
\end{tabular}

** Significant at 0.01 level, *Significant at 0.05 level

How to cite this article: K Singh, M Raju, N Choudhri, T Devi, O Patel, S Das (2016), Protocols of Alcohol Dependents on Rorschach, International Journal of Indian Psychology, Volume 4, Issue 1, No. 79, ISSN:2348-5396 (e), ISSN:2349-3429 (p), DIP:18.01.089/20160304, ISBN:978-1-365-56745-2 